Volume 7

Number 3 Oil \& Gas Survey

$5-12-2021$

\title{
Federal Legal and Regulatory Developments Relating to the U.S. Pipeline Industry
}

Chloe J. Marie

cjm445@psu.edu

Ross Pifer

Penn State Law, rhp102@psu.edu

Follow this and additional works at: https://scholarship.law.tamu.edu/journal-of-property-law

Part of the Oil, Gas, and Mineral Law Commons, and the Property Law and Real Estate Commons

\section{Recommended Citation}

Chloe J. Marie \& Ross Pifer, Federal Legal and Regulatory Developments Relating to the U.S. Pipeline Industry, 7 Tex. A\&M J. Prop. L. 495 (2021).

Available at: https://doi.org/10.37419/JPL.V7.I3.17

This Student Article is brought to you for free and open access by Texas A\&M Law Scholarship. It has been accepted for inclusion in Texas A\&M Journal of Property Law by an authorized editor of Texas A\&M Law Scholarship. For more information, please contact aretteen@law.tamu.edu. 


\title{
Federal Legal and Regulatory DeVelopments Relating TO THE U.S. PIPELINE INDUSTRY
}

\author{
Chloe J. Marie \& Ross H. Pifer ${ }^{\dagger}$
}

\section{INTRODUCTION}

The Atlantic Coast Pipeline (“ACP”) was designed as a 600-mile underground, pipeline project transporting natural gas from well sites in West Virginia to end users throughout Virginia and North Carolina. ${ }^{1}$ Atlantic Coast Pipeline, LLC ("Atlantic Coast"), the developer of the ACP project, began the extensive process of obtaining the necessary regulatory approvals for this project by initiating a pre-filing process with the Federal Energy Regulatory Commission ("FERC") in October 2014. In the nearly six years that followed, the project received various permits related to water and air quality as well as other matters from state and federal agencies. At nearly every step of the way, however, opponents of the project challenged the grant of these permits. $^{2}$ In one case, several environmental groups challenged the propriety of the U.S. Forest Service granting a right-of-way for the pipeline to traverse a portion of the Appalachian National Scenic Trail. The ensuing litigation eventually reached the U.S. Supreme Court, which rendered an opinion on June 15, 2020, upholding the grant of the right-of-way and apparently paving the way for the completion of the project. ${ }^{3}$ Despite

DOI: https://doi.org/10.37419/JPL.V7.I3.17

$\uparrow$ Chloe Marie is a Research Specialist at the Center for Agricultural and Shale Law, Penn State Law. Ross H. Pifer is the Associate Dean for Clinics and Experiential Learning, Director of the Center for Agricultural and Shale Law, Penn State Law. The copyright for this article has been retained by the authors, all rights reserved.
1. Powering
ATLANTIC
COAST
PIPELINE,

https://atlanticcoastpipeline.com/resources/docs/resources/acp-

factbookversion2.pdf [https://perma.cc/NA6D-5RQQ].

2. See Appalachian Voices v. State Water Control Bd., 912 F.3d 746, 750-52 (4th Cir. 2019); see_Sierra Club v. United States Dep't of the Interior, 899 F.3d 260, 265-66 (4th Cir. 2018); see Defs. of Wildlife v. U.S. Dep't of the Interior, 931 F.3d 339, 343-44 (4th Cir. 2019); see Cowpasture River Pres. Ass'n v. Forest Serv., 911 F.3d 150, 154-56 (4th Cir. 2018); see Defs. of Wildlife v. United States Dep't of the Interior, 931 F.3d 339, 342-44 (4th Cir. 2019); see Sierra Club v. United States Army Corps of Engineers, 735 F. App'x 103, 103-04 (4th Cir. 2018).

3. United States Forest Serv. v. Cowpasture River Pres. Ass'n, 140 S. Ct. 1837, 
receiving this favorable ruling, Duke Energy and Dominion Energythe companies that created Atlantic Coast Pipeline, LLC as a joint venture - announced they were abandoning construction of the project on July $5,2020 .{ }^{4}$

Why would Duke Energy and Dominion Energy abandon the ACP project less than three weeks after the U.S. Supreme Court gave them a green light on a critical aspect of the project? The answer to that question largely comes from a legal development relating to the Keystone XL Pipeline, ${ }^{5}$ which like the ACP project, has been the subject of frequent litigation as it has moved through the required regulatory processes. In one of the court cases challenging construction of the Keystone XL Pipeline, Nationwide Permit 12 ("NWP 12") - a general permit under the Clean Water Act-was vacated. ${ }^{6}$ As a result of the vacatur of this permit, Duke Energy and Dominion Energy determined that there were too many uncertainties regarding the economic viability of the ACP project to continue moving forward. ${ }^{7}$

The legal developments surrounding the ACP project-and its ultimate fate - provide an illustration of the current landscape facing the oil and gas industry. In the construction of pipeline infrastructure, upstream and midstream companies should expect to face legal challenges throughout the entire permitting process. Advocates opposed to fossil fuel extraction and production generally as well as groups and individuals who have objections to the localized impacts from a specific pipeline project are likely to initiate those legal challenges. $^{8}$

1841, 1850 (2020).

4. See Dominion Energy and Duke Energy Cancel the Atlantic Coast Pipeline, DOMINION ENERGY (July 5, 2020), https://news.dominionenergy.com/2020-07-05Dominion-Energy-and-Duke-Energy-Cancel-the-Atlantic-Coast-Pipeline [https://perma.cc/H2AE-9RQK] [hereinafter Cancel the Pipeline].

5. See John Downy, Duke Energy, Dominion abandon the $\$ 8$ billion Atlantic Coast Pipeline, CHARlOTTE Bus. J. (July 6, 2020), https://www.bizjournals.com/charlotte/news/2020/07/05/duke-energy-dominionabandon-the-atlantic-coast-p.html [https://perma.cc/XK9G-VGDV].

6. N. Plains Res. Council v. U.S. Army Corps of Engineers, No. CV 19-44-GFBMM, 2020 WL 3638125, at *1, *14 (D. Mont. May 11, 2020).

7. See Cancel the Pipeline, supra note 5.

8. See Marianne Lavelle, Climate Activists See 'New Era' After Three Major Oil and Gas Pipeline Defeats, Inside Climate News (July 7, 2020), https://insideclimatenews.org/news/07072020/pipeline-climate-victories-dakotaaccess-keystone-xl-atlantic-coast [https://perma.cc/Z8CF-WSDU]; see Valerie Volcovici \& Stephanie Kelly, End of an era? Series of U.S. Setbacks Bodes Ill for Big Oil, Gas Pipeline Projects, REUTERS (July 8, 2020), 
This Article will address legal and regulatory developments at the federal level regarding five major pipeline projects-Atlantic Coast Pipeline; Dakota Access Pipeline; Keystone XL Pipeline; Mountain Valley Pipeline; and PennEast Pipeline-during the period from September 1, 2019, to September 1, 2020. There also have been a number of legal and regulatory developments relating to other pipeline projects during the past year, but those developments are beyond the scope of this Article. ${ }^{9}$

\section{ATLANTIC COAST PIPELINE}

The ACP project proposed to transport gas from wells in Harrison County, West Virginia, through Virginia to a terminal facility in Robeson County, North Carolina. On June 15, 2020, the U.S. Supreme

https:/www.reuters.com/article/us-usa-pipelines/end-of-an-era-series-of-u-ssetbacks-bodes-ill-for-big-oil-gas-pipeline-projects-idUSKBN2491M5 [https://perma.cc/336E-XYDW]; see Keystone XL Pipeline, CTR. FOR BIOLOGICAL DIVERSITY, https://www.biologicaldiversity.org/programs/public_lands/energy/key stone_xl_pipeline [https://perma.cc/U546-EPHU]; see Pipeline Risks, TIP OF THE MITT WATERSHED COUNCIL, https://www.watershedcouncil.org/pipeline-risks.html [https://perma.cc/KH2S-VYGR]; see Chiara Belvederesi et al., Statistical Analysis of Environmental Consequences of Hazardous Liquid Pipeline Accidents, HELIYON (Oct. 29, 2018), https://www.ncbi.nlm.nih.gov/pmc/articles/PMC6226826/pdf/main .pdf [https://perma.cc/Y4KN-SSBV].

9. Jackie Schweichler, Shale Law Weekly Review - January 3, 2020, PENN ST. SHALE L. BLOG (Jan. 4, 2020), http://www.pennstateshalelaw.com/search?q=adelphia [https://perma.cc/LM2SQ3BW]; Chloe Marie, Shale Law in the Spotlight: Constitution Pipeline ProjectAn Overview of Status and Current Legal Developments, PENN ST. SHALE L. Blog (April 25, 2018), http://www.pennstateshalelaw.com/search?q=constitution [https://perma.cc/GAC8-JHWG]; Sara Jenkins et al., Shale Law Weekly ReviewMay 12, 2020, PenN St. Shale L. Blog (May 12, 2020), http://www.pennstateshalelaw.com/search?q=kinder+morgan

[https://perma.cc/JMU8-S5UH]; Chloe Marie, Shale Law in the Spotlight: Mariner East Pipeline - An Overview of Status and Current Regulatory Developments, PENN ST. SHAlE L. BloG (May 9, 2020), http://www.pennstateshalelaw.com/search?q=mariner [https://perma.cc/3LQYUZFM]; Chloe Marie, Shale Law in the Spotlight: Valley Lateral Pipeline ProjectAn Overview of Status and Current Legal Developments, PENN ST. SHALE L. Blog (April 4, 2018), http://www.pennstateshalelaw.com/search?q=millennium [https://perma.cc/Z2HW-6HUA]; Chloe Marie, Shale Law in the Spotlight: Overview of Legal Developments on the Atlantic Sunrise Pipeline Project, PENN ST. SHALE L. BLOG (SEPT. 13, 2017), http://www.pennstateshalelaw.com/search?q=transcontinental

[https://perma.cc/XRU2-4VP6]; Chloe Marie \& Jackie Schweichler, Shale Law Weekly Review - November 4, 2019, PenN St. Shale L. Blog (Nov. 2, 2019), http://www.pennstateshalelaw.com/search? $\mathrm{q}=$ spire [https://perma.cc/5LVKVD6X]. 
Court issued an opinion addressing whether the U.S. Forest Service had the authority to grant a right-of-way to Atlantic Coast for the construction of a pipeline that would cross the Appalachian National Scenic Trail (the "Appalachian Trail"). The Court answered this question in the affirmative, holding that the Forest Service has jurisdiction over all federal lands within the National Forest System even if those federal lands are crossed by a trail administered by the National Park Service. ${ }^{10}$

The background for this litigation originated in January 2018 when the Forest Service granted Atlantic Coast a Special Use Permit. ${ }^{11}$ This Special Use Permit authorized the use and occupancy of National Forest System ("NFS") lands for the construction and operation of the ACP project and granted a right-of-way across the Appalachian Trail, which traverses the George Washington National Forest. Subsequently, in February 2018, the Cowpasture River Preservation Association along with six other environmental conservation groups filed a joint petition before the U.S. Court of Appeals requesting judicial review of the permit. ${ }^{12}$

The environmental groups argued that the Forest Service did not have statutory authority to grant a right-of-way across the Appalachian Trail, and by doing so, it violated the Mineral Leasing Act and National Trails System Act. ${ }^{13}$ The court of appeals agreed with the petitioners and vacated the Special Use Permit, concluding that the Forest Service did not have the authority to grant Atlantic Coast a right-of-way across the Appalachian Trail. ${ }^{14}$ Thereafter, the Forest Service filed a petition with the U.S. Supreme Court in June 2019 seeking certiorari to appeal the court of appeals's decision. The Supreme Court agreed to hear the case on October 4, 2019, to address the extent of the Forest Service's statutory authority to grant a pipeline right-of-way in this case.

10. United States Forest Serv. v. Cowpasture River Pres. Ass'n, 140 S. Ct. 1837, 1841, 1844 (2020).

11. See Special Use Permit, U.S. DeP'T OF AGRIC. Forest SerV., (Feb. 8, 2018), https://www.fs.usda.gov/Internet/FSE_DOCUMENTS/fseprd571995.pdf [https://perma.cc/9YHB-H2CZ].

12. Cowpasture River Pres. Ass'n v. Forest Serv., 911 F.3d 150, 154-56 (4th Cir. 2018).

13. United States Forest Serv. v. Cowpasture River Pres. Ass'n, 140 S. Ct. 1837, $1842(2020)$.

14. Cowpasture River Pres. Ass'n v. Forest Serv., 911 F.3d 150, 155 (4th Cir. 2018), rev'd and remanded sub nom. United States Forest Serv. v. Cowpasture River Pres. Ass'n, 140 S. Ct. 1837 (2020). 
In its opinion, the Supreme Court reviewed the significance of the interests and authority provided to the agencies under the National Trails System Act. The Court explained that although the Forest Service had granted rights-of-way to the National Park Service pursuant to the National Trails System Act for nearly 780 miles of trail routes within national forests across the Appalachia Trail, the federal lands subject to the rights-of-way did not become lands within the National Park System. To articulate its point, the Court drew an analogy to the rights of private landowners in the same situation and stressed the non-possessory characteristic of a right-of-way that is limited to a specific use of the subject land. ${ }^{15}$ As such, the Court reversed and remanded the vacation of the Special Use Permit and right-of-way, holding that "the Department of the Interior's decision to assign responsibility over the Appalachian Trail to the National Park Service did not transform the land over which the Trail passes into land within the National Park System." 16 Thus, the Court concluded that the Forest Service did have the statutory authority to grant a pipeline right-of-way across the Appalachian Trail for the ACP project. ${ }^{17}$

In addition to the right-of-way issue addressed by the U.S. Supreme Court, the U.S. Court of Appeals for the Fourth Circuit addressed, in a separate case, the propriety of the issuance of a state air permit for the ACP project. On January 7, 2020, the court of appeals vacated a key air permit to construct and operate a compressor station in Buckingham County, Virginia. ${ }^{18}$ The Virginia Department of Environmental Quality and the Virginia Air Pollution Control Board (the "Board") issued a minor, new source review air permit on January 9, 2019, for construction of the Buckingham Compressor Station to support the ACP project. On February 8, 2019, a group of citizens from Buckingham County, Virginia - known as the Friends of Buckingham - petitioned the court of appeals for judicial review of this permit. ${ }^{19}$ The petitioners argued that the Board did not sufficiently considered whether the specific location chosen-Union Hill—was a "suitable" site for the compressor station. ${ }^{20}$ The court of appeals

15. United States Forest Serv. v. Cowpasture River Pres. Ass'n, 140 S. Ct. 1837, 1845 (2020).

16. Id. at 1850 .

17. $I d$.

18. Friends of Buckingham v. State Air Pollution Control Bd., 947 F.3d 68, 93 (4th Cir. 2020).

19. Id. at 71 .

20. Id. In addition, petitioners claimed that the Board failed to "consider electric 
agreed with the petitioners, concluding that "the Board failed in its statutory duty to determine the character and degree of injury to the health of the Union Hill residents and the suitability of the activity to the area." 21

\section{DAKotA ACCESS PIPELINE}

The Dakota Access Pipeline is a 1,172-mile pipeline project designed to carry crude oil from the Three Forks formation in North Dakota to Patoka, Illinois. ${ }^{22}$ The pipeline is operational throughout much of its length, and it has transported approximately 570,000 barrels of oil on a daily basis. ${ }^{23}$ The Dakota Access Pipeline gained national attention due to the extensive protests that took place in North Dakota against the continuing construction of the pipeline near Native American lands. ${ }^{24}$

The construction and operation of the Dakota Access Pipeline currently faces a legal challenge in the U.S. District Court for the District of Columbia from parties including the Standing Rock Sioux Tribe (the "Tribe"), which initially filed its complaint in $2016 .{ }^{25}$ The Standing Rock Sioux Tribe alleged that the pipeline construction will cause negative environmental and cultural impacts due to its crossing near or under Lake Oahe, which is located on the east side of the Standing Rock Indian Reservation. ${ }^{26}$ The Tribe expressed concerns that the pipeline construction may affect historic properties and

turbines as zero-emission alternatives to gas-fired turbines" and that the Board also failed "to assess the Compressor Station's potential for disproportionate health impacts on the predominantly African-American community of Union Hill."

21. $I d$. at 86 .

22. Moving America's Energy: The Dakota Access Pipeline, DAKOTA ACCESS PIPELINE (Oct. 26, 2020), https://daplpipelinefacts.com/ [https://perma.cc/U3STYCJP].

23. Id.

24. In September 2019, a federal grand jury in the U.S. District Court for the Southern District of Iowa indicted in two protestors for their actions relating to the Dakota Access Pipeline in United States v. Reznicek, No. 4:19-CR-172 (S.D. Iowa filed Sept. 19, 2020). The protestors, Jessica R. Reznicek and Ruby K. Montoya, were charged with one count of conspiracy to damage the property of an energy facility, four counts of use of fire in the commission of a felony, and four counts of malicious use of fire.

25. Standing Rock Sioux Tribe v. U.S. Army Corps of Eng'rs, 255 F. Supp. 3d 101, 111 (D.D.C. 2017).

26. Complaint for Declaratory \& Injunctive Relief at 1-2, Standing Rock Sioux Tribe v. U.S. Army Corps of Eng'rs, 440 F.Supp.3d 1 (D.D.C. 2020) (No. 16-1534). 
federally regulated waters on the Tribe's land in the event of a leak or spill. $^{27}$

In July 2016, the U.S. Army Corps of Engineers (the "Corps") published a Final Environmental Assessment along with a Mitigated Finding of No Significant Impact, concluding that there was no need to prepare an Environmental Impact Statement ("EIS"). As a result, the Corps granted an easement to Dakota Access Pipeline, LLC ("Dakota Access") in February 2017 allowing construction of a portion of the Dakota Access Pipeline to cross near or under Lake Oahe. $^{28}$

The plaintiffs disputed the Corps' conclusion that an EIS was not necessary, claiming that the potential harmful effects of an oil spill upon the Tribe should have triggered the preparation of an EIS. ${ }^{29}$ On March 25, 2020, the district court sided with the plaintiffs and ordered the Corps to produce an EIS. ${ }^{30}$ Addressing the plaintiffs' many environmental concerns, the district court held that " $[\mathrm{u}]$ nrebutted expert critiques regarding leak-detection systems, operator safety records, adverse conditions, and worst-case discharge mean that the easement approval remains 'highly controversial' under NEPA," and therefore a remand of this matter was necessary. ${ }^{31}$ Additionally, the district court directed both parties to address the issue of whether shutting down the pipeline was an appropriate remedy during the remand. $^{32}$

On July 6, 2020, the district court vacated the Corps's easement approval and shut down the Dakota Access Pipeline. ${ }^{33}$ The district court further ordered Dakota Access to empty the pipeline by August 5, 2020. ${ }^{34}$ Acknowledging that a shutdown order would significantly hurt the North Dakota oil industry, the court observed that "[c]lear precedent favoring vacatur during such a remand coupled with the seriousness of the Corps's deficiencies outweighs the negative effect of halting the oil flow for the thirteen months that the Corps believes the creation of an EIS will take." 35

27. $I d$. at $20-21$.

28. Standing Rock Sioux Tribe v. U.S. Army Corps of Eng'rs, 440 F.Supp.3d 1, 1, 10 (D.D.C. 2020).

29. Id. at 14 .

30. Id. at 30 .

31. Id. at 8 .

32. Id. at 29-30.

33. Cheyenne River Sioux Tribe v. U.S. Army Corps of Eng'rs, No. 16-1534, 2020 WL 3634426, at *11 (D.D.C. July 6, 2020).

34. Id. at $* 10$.

35. Id. at $* 1$. 
Dakota Access immediately filed an emergency motion with the district court to stay the July shut down order pending an appeal. ${ }^{36}$ The district court, however, rejected the motion on July 9, 2020, contending there was no basis for a stay. ${ }^{37}$ As expected, on July 13, 2020, the Corps appealed the district court's March 25, 2020, and July 9, 2020, orders to the U.S. Court of Appeals for the District of Columbia Circuit. ${ }^{38}$

On July 14, 2020, the court of appeals issued an administrative stay of the district court's July shut down order pending further proceedings but specified that this administrative stay should not be perceived as a ruling on the merits of that motion, but rather as a means to provide the court of appeals with time to render a sound decision on the emergency motion for stay. ${ }^{39}$

On August 5, 2020, the court of appeals rendered its judgment, ruling that a stay of the district court's shutdown order was warranted because the "district court did not make the findings necessary for injunctive relief." 40 The court of appeals, however, also rejected the Corps's emergency motion to stay the district court's order that vacated the easement allowing the Dakota Access Pipeline to cross Lake Oahe. ${ }^{41}$ In this regard, the court of appeals opined, "[a]t this juncture, appellants have failed to make a strong showing of likely success on their claims that the district court erred in directing the Corps to prepare an environmental impact statement." 42 Thus, following the series of court orders issued by the district court and court of appeals, Dakota Access no longer held an easement on the land through which the pipeline passes. In light of this fact, the court of appeals, in its August 5 order, requested that the Corps provide

36. Dakota Access, LLC's Emergency Motion to Provisionally Stay Remedy Order and Set Expedited Briefing Schedule for Motion for Stay Pending Appeal at 1, Standing Rock Sioux Tribe v. U.S. Army Corps of Eng'rs, 440 F.Supp.3d 1 (D.D.C. 2020) (No. 16-1534).

37. Order Denying Motion for Stay Pending Appeal at 2, Standing Rock Sioux Tribe v. U.S. Army Corps of Eng'rs, 440 F.Supp.3d 1 (D.D.C. 2020) (No. 16-1534).

38. Standing Rock Sioux Tribe v. U.S. Army Corps of Eng'rs, 440 F.Supp.3d 1 (D.D.C. 2020), appeal docketed, No. 20-5201 (D.C. Cir. July 13, 2020).

39. Standing Rock Sioux Tribe v. U.S. Army Corps of Eng'rs, No. 20-5197 (D.C. Cir. July 14, 2020) (per curiam order).

40. Standing Rock Sioux Tribe v. U.S. Army Corps of Eng'rs, No. 20-5197 (D.C. Cir. Aug. 5, 2020) (per curiam order). The Court of Appeals lifted the July 14, 2020 administrative stay and delivered its decision relating to the other orders.

41. Standing Rock Sioux Tribe v. U.S. Army Corps of Eng'rs, No. 20-5197 (D.C. Cir. Aug. 5, 2020) (per curiam order).

42. Id. 
clarification as to how the pipeline was going to operate in the absence of an easement. ${ }^{43}$

\section{KeYstone XL PIPELINE}

On July 6, 2020, the U.S. Supreme Court issued an important ruling regarding the Keystone XL Pipeline, albeit in an order that the Court issued without an accompanying opinion. This order halted construction on the pipeline. ${ }^{44}$ In the underlying litigation, the U.S. District Court for the District of Montana vacated the use of NWP 12 for the construction and operation of utility lines, including oil and natural gas pipelines. The district court further enjoined the Corps from using NWP 12 for any related activities, pending consultation and compliance with Section 7 of the Endangered Species Act ("ESA"). ${ }^{45}$ In making this ruling, the district court concluded that the 2017 reissuance of NWP 12 violated Section 7 of the ESA as the Corps failed to undertake a formal programmatic consultation with the Fish and Wildlife Service ("FWS") and the National Marine Fisheries Service ("NMSS"). ${ }^{46}$ On May 11, 2020, the district court amended its order by narrowing the vacatur and injunction remedies to the construction of new oil and gas pipelines. ${ }^{47}$

The Corps appealed to the U.S. Court of Appeals for the Ninth Circuit on May 13, 2020, and later filed an emergency motion for a partial stay of both district court orders pending appeal. ${ }^{48}$ The court of appeals rejected their emergency motion on May 28, 2020.49 Subsequently, on June 15, 2020, the Corps requested that the U.S. Supreme Court stay the district court's amended order during the pendency of the appeal with the court of appeals. ${ }^{50}$

In its application for a stay, the Corps expressed concern that the district court vacated and enjoined the use of NWP 12 for the

43. Id.

44. U.S. Army Corps of Eng'rs v. N. Plains Res. Council, No. 19-A1053, 2020 WL 3637662 (U.S. July 6, 2020).

45. N. Plains Res. Council v. U.S. Army Corps of Eng'rs, 454 F. Supp. 3d 985, 994 (D. Mont. 2020).

46. Application for a Stay Pending Appeal at 12, U.S. Army Corps of Eng'rs v. N. Plains Res. Council, No. 19-A1053 (U.S. Jun. 15, 2020).

47. N. Plains Res. Council v. U.S. Army Corps of Eng'rs, 460 F. Supp. 3d 1030, 1043 (D. Mont. 2020) (amended order).

48. N. Plains Res. Council v. U.S. Army Corps of Eng'rs, No. 20-35412 (9th Cir. May 28, 2020) (order).

49. Id.

50. Application for a Stay Pending Appeal, U.S. Army Corps of Eng'rs v. N. Plains Res. Council, No. 19A1053 (U.S. Jun. 15, 2020). 
construction of utility lines "without any explanation" in an action where the respondents sought a remedy aimed only at the Keystone XL Pipeline and did not include any other pipelines in their initial request. ${ }^{51}$ The Corps also argued that the respondents did not make factual allegations that could be used to establish an injury in fact resulting from the construction of any other pipelines, and therefore they failed to demonstrate standing under Article III of the U.S. Constitution. ${ }^{52}$ Furthermore, the Corps contended that a programmatic consultation was not necessary under Section 7 of the ESA for the purpose of reissuing the NWP $12 .{ }^{53}$ In summary, the Corps claimed that the district court's order to vacate NWP 12 for new oil and gas pipelines would put a strain on the Corps' ability to deliver permits in a timely manner and would "threaten[] to cause immediate and ongoing harm to the Nation's energy industry and to the many public and private entities and individuals who rely on oil and gas pipelines." 54

In its order issued on July 6, 2020, the U.S. Supreme Court granted the Corps' request in part by limiting the application of the district court order to the Keystone XL Pipeline. ${ }^{55}$ Thus, at this point, the Corps can continue to utilize NWP 12 for other projects, but construction of the Keystone XL Pipeline has been halted. ${ }^{56}$

\section{MOUNTAIN VALLEy PIPELINE}

The Mountain Valley Pipeline ("MVP") project consists of a proposed 303-mile interstate pipeline system designed to transport natural gas from Wetzel County in northwestern West Virginia to

51. Id. at $15-16$.

52. Id. at $22-24$.

53. Application for a Stay Pending Appeal to the U.S. Court of Appeals for the Ninth Circuit \& Pending Further Proceedings in this Court at 30-31, United States Army Corps of Eng'rs v. N. Plains Res. Council, No. 19A1053, 2020 WL 3637662 (July 6, 2020).

54. Id. at 21 .

55. United States Army Corps of Eng'rs v. N. Plains Res. Council, No. 19A1053, 2020 WL 3637662 , at *1 (July 6, 2020) ("The application for a stay presented to Justice Kagan and by her referred to the Court is granted in part and denied in part. The district court's May 11,2020 order granting partial vacatur and an injunction is stayed, except as it applies to the Keystone XL Pipeline, pending disposition of the appeal in the United States Court of Appeals for the Ninth Circuit and disposition of the petition for a writ of certiorari, if such writ is timely sought. Should the petition for a writ of certiorari be denied, this stay shall terminate automatically. In the event the petition for a writ of certiorari is granted, the stay shall terminate upon the sending down of the judgment of this Court.").

56. See id. 
Pittsylvania County in southern Virginia. ${ }^{57}$ Construction on this pipeline project began in February 2018. ${ }^{58}$ The MVP project has been the subject of extensive litigation, resulting in a cessation of construction in October 2019 due to questions surrounding a key document - the Biological Opinion ("BiOp") and Incidental Take Statement ("ITS"). ${ }^{59}$

In August 2019, a coalition of environmental groups petitioned the U.S. Court of Appeals for the Fourth Circuit seeking judicial review of the FWS BiOp and ITS for the MVP project that was issued in November 2017. ${ }^{60} \mathrm{~A}$ few days later, the petitioners filed a motion for stay of the BiOp and ITS pending the appeal. The petitioners alleged that FWS failed to consider certain aspects of the project in its analysis that would significantly affect several threatened and endangered species, including the Indiana and Northern long-eared bat species and Roanoke Logperch. ${ }^{61}$ In response, the U.S. Department of the Interior requested that the court of appeals hold the proceedings in abeyance until January 11, 2020, so that FERC and FWS could consult each other to revise the BiOp and any other relevant documents. ${ }^{62}$

On October 11, 2019, the court of appeals entered an order staying the $2017 \mathrm{BiOp}$ and ITS pending appeal and holding the case in abeyance for the time requested. ${ }^{63}$ Subsequently, on October 15, 2019, FERC issued a cease work order to Mountain Valley Pipeline, LLC

57. Mountain Value Pipeline Project, MoUnTAIN VALlEY PIPELINE, https://www.mountainvalleypipeline.info/ [https://perma.cc/L2P2-MA62].

58. See Overview, MOUNTAIN VALLEY PIPELINE, https://www.mountainvalleypipeline.info/overview/ [https://perma.cc/VR7BLXJE].

59. See, e.g., Sierra Club v. W. Va. Dep't of Envtl. Prot., No. 17-1714, ECF No. 3 (4th Cir. June 9, 2017); Berkley v. Mountain Valley Pipeline, LLC, No. 7:17-cv00357, 2017 WL 6327829 (W.D. Va. Dec. 11, 2017); Bold Alliance v. FERC, No. 17-cv-01822, 2018 WL 4681004 (D.D.C. Sept. 27, 2018); Sierra Club v. U.S. Army Corps of Eng'rs, 909 F.3d 635 (4th Cir. 2018); Mountain Valley Pipeline, LLC v. 6.56 Acres of Land, 915 F.3d 197 (4th Cir. 2019); Mountain Valley Pipeline, LLC v. Simmons, 307 F. Supp. 3d 506 (N.D. W. Va. 2018); Sierra Club, Inc. v. U.S. Forest Serv., 897 F.3d 582 (4th Cir. 2018); Sierra Club v. State Water Control Bd., 898 F.3d 383 (4th Cir. 2018); Appalachian Voices v. Fed. Energy Regulatory Comm'n, No. 17-1271, 2019 WL 847199 (D.C. Cir. Feb. 19, 2019).

60. Petition for Review of Agency Order, Wild Va. v. U.S. Dep't of the Interior, No. 19-1866 (4th Cir. Aug. 12, 2019).

61. Petitioners' Motion for Stay of Respondent U.S. Fish \& Wildlife Service's Biological Opinion \& Incidental Take Statement at 1-2, Wild Va. v. U.S. Dep't of the Interior, No. 19-1866 (4th Cir. Aug. 21, 2019).

62. Respondents' Opposition to Motion \& Motion for Abeyance, Wild Va. v. United States Dep't of the Interior, No. 19-1866 (4th Cir. Aug. 29, 2019).

63. Wild Va. v. U.S. Dep't of the Interior, No. 19-1866 (4th Cir. Oct. 11, 2019) (order). 
("Mountain Valley") "along all portions of the [MVP] [p]roject and in all work areas ...." The cease work order did allow Mountain Valley to continue work but solely for the purpose of stabilizing and restoring disturbed lands. ${ }^{64}$ From January 2020 to April 2020, the U.S. Department of the Interior and Mountain Valley sought to extend the abeyance of the proceedings, and on April 28, 2020, the court of appeals agreed to hold the case until the FWS issued a new BiOp and ITS. ${ }^{65}$

As these issues regarding FWS actions were being litigated, on February 14, 2020, FERC issued a final EIS for the construction of the MVP Southgate Expansion Project. ${ }^{66}$ The proposed Southgate Project would add seventy-five miles to the MVP and is designed to receive natural gas from the MVP in Pittsylvania County, Virginia, and carry it to new delivery points located in Rockingham and Alamance Counties, North Carolina. ${ }^{67}$ On June 18, 2020, FERC granted Mountain Valley a certificate to construct and operate the proposed Southgate Project pipeline. ${ }^{68}$

In a news release on June 11, 2020, Mountain Valley announced an adapted schedule for the construction completion of the MVP. ${ }^{69}$ The news release stated that $92 \%$ of the construction was completed, and the expected commercial-in-service date was scheduled for early 2021. ${ }^{70}$ Subsequently, on August 25, 2020, Mountain Valley filed with FERC a request for an extension of time to complete the MVP project

64. Email from Terry L. Turpin, Director, Office of Energy Projects, to Matthew Eggerding, Counsel for Mountain Valley Pipeline, LLC (Oct. 15, 2019) https://elibrary.ferc.gov/idmws/file_list.asp?accession_num=20191015-3030 [https://perma.cc/WWG7-Q5DR].

65. Wild Va. v. U.S. Dep't of the Interior, No. 19-1866 (4th Cir. Jan. 9, 2020) (order granting motion to continue abeyance); Wild Va. v. U.S. Dep't of the Interior, No. 19-1866 (4th Cir. Mar. 11, 2020) (order granting motion to continue abeyance); Wild Va. v. U.S. Dep't of the Interior, No. 19-1866 (4th Cir. Apr. 28, 2020) (order granting motion to continued abeyance).

66. FERC Staff, Final Environmental Impact Statement for Southgate Project, FERC (Feb. 14, 2020), https://www.ferc.gov/final-environmental-impactstatement-southgate-project [https://perma.cc/Q5WB-JD8N].

67. American Pipeline delivering American Energy, MVP SouthGate, http://www.mvpsouthgate.com/ [https://perma.cc/M4DJ-7RCP].

68. Fed. ENERGy REg. COMM'N, 171 FERC đ 61,232 (June 18, 2020), https:/www.ferc.gov/sites/default/files/2020-06/C-6-061820.pdf [https://perma.cc/7WZR-6R3K].

69. News Releases, MVP Prepares for Construction Completion, MounTAIN VALLEY PIPELINE (June 11, 2020), https://www.mountainvalleypipeline.info/wpcontent/uploads/2020/06/Schedule-Cost-AppTrail-June-2020-FINAL3.pdf [https://perma.cc/645U-HZC2].

70. Id. 
from October 13, 2020, until October 13, 2022. ${ }^{71}$ Mountain Valley cited various lawsuits and permitting issues as reasons for the delay in project completion. ${ }^{72}$ In its news release, Mountain Valley predicted that total project costs may increase by $5 \%$ compared to the company's initial estimate of $\$ 5.4$ billion. ${ }^{73}$ This increased cost projection was due mainly to delays in the construction of the pipeline caused by litigation. $^{74}$

\section{PENNEAst PiPELINE}

The PennEast Pipeline project is a 120-mile expansion project proposed by PennEast Pipeline Company, LLC ("PennEast") to transport natural gas from Luzerne County in northeastern Pennsylvania to the existing Transco pipeline interconnection located near Pennington, Mercer County, New Jersey. ${ }^{75}$ To secure the necessary easements for this pipeline project, PennEast brought condemnation actions in February 2018 before the U.S. District Court for the District of New Jersey. ${ }^{76}$ In December 2018, the district court allowed PennEast to take rights associated with private- and stateowned properties to build the pipeline project. The court also granted PennEast's request for injunctive relief to obtain immediate access to

71. Fed. Energy Reg. Comm'N, Mountain Valley Pipeline, LlC; Notice of REQUEST FOR EXTENSION OF TIME, 85 FR 54, 553 (Sept. 2, 2020), https://www.federalregister.gov/documents/2020/09/02/2020-19376/mountain-

valley-pipeline-llc-notice-of-request-for-extension-of-time

[https://perma.cc/3XCF-HUJZ].

72. Id. at 54,554 .

73. News Releases, MVP Prepares for Construction Completion, MounTAIN VALLEY PIPELINE (June 11, 2020), https://www.mountainvalleypipeline.info/wpcontent/uploads/2020/06/Schedule-Cost-AppTrail-June-2020-FINAL3.pdf

[https://perma.cc/645U-HZC2].

74. Id.

75. Overview, PENNEAST PIPELINE, https://penneastpipeline.com/overview/ [https://perma.cc/HZ8Y-52ZM].

76. In re PennEast Pipeline Co., No. 18-1585, 2018 WL 6584893, at *6 (D.N.J. Dec. 14, 2018) (PennEast Pipeline Company filed a complaint in condemnation on Feb. 6, 2018, pursuant to Section 7(h) of the Natural Gas Act, claiming the necessary rights-of-way and easements in property, including state-owned property, for the construction of the PennEast Pipeline after it failed to negotiate directly with landowners on the issue of compensation. PennEast also sought injunctive relief for immediate access to property.). 
the properties. ${ }^{77}$ The State of New Jersey appealed this decision to the U.S. Court of Appeals for the Third Circuit. ${ }^{78}$

That this eminent domain action targeted some state-owned lands raised a constitutional question regarding the application of the 11th Amendment to the U.S. Constitution. Generally, this constitutional provision protects states from being sued in federal court, but the federal government holds an exemption authorizing it to sue states. While the federal government has delegated the power of eminent domain to private companies under the Natural Gas Act ("NGA"), the parties disputed the manner in which the 11th Amendment applied to this eminent domain action.

On September 10, 2019, the court of appeals concluded that PennEast was prevented from suing the State of New Jersey to obtain rights-of-way and easements through the eminent domain process. Thus, the court vacated and remanded the case to the district court for further proceedings. In its opinion, the court of appeals concluded that the delegation of federal power for eminent domain to private companies did not provide them with the power to condemn stateowned properties and explained that " $\mathrm{t}] \mathrm{he}$ federal government's power of eminent domain and its power to hale sovereign [s]tates into federal court are separate and distinct."79

Following the court of appeals' ruling, on October 8, 2019, the New Jersey Department of Environmental Protection ("DEP"), one of the state parties in this lawsuit, denied PennEast's application for a Freshwater Wetlands Individual Permit and Water Quality Certification, which was a key document necessary for construction of the pipeline project.

On November 5, 2019, the court of appeals denied PennEast's petition for rehearing, and on December 16, 2019, the U.S. District Court for the District of New Jersey vacated its prior order, dated December 2018, with respect to the property interests owned by the

77. Id. at $* 12, * 26$ (The District Court denied the State Defendants' request for dismissal of the condemnation proceedings. The Court noted that FERC's granting of a valid certificate of public convenience and necessity under the NGA gives companies the right to directly sue any state government for eminent domain purposes and asked the State Defendants to show evidence as to why the 11th Amendment's sovereign immunity would apply in this case.).

78. In re PennEast Pipeline Co., 938 F.3d 96 (3d Cir. 2019) (The U.S. Court of Appeals agreed on March 19, 2019 to hear the appeal on an expedited schedule and to stay the construction of the PennEast Pipeline in New Jersey pending the outcome of this appeal.).

79. Id. at 100 . 
State of New Jersey. Additionally, the district court dismissed all claims filed against the state defendants.

Thereafter, on February 18, 2020, PennEast filed a petition for writ of certiorari with the U.S. Supreme Court seeking to overturn the court of appeals' decision that eminent domain could not be exercised on property in which a state has an interest. On June 29, 2020, the Supreme Court invited the U.S. Solicitor General to file a brief in the pending case to express the position of the United States in this matter. ${ }^{80}$

\section{CONCLUSION}

Over the past decade, the United States has become the world's largest producer of oil and natural gas. ${ }^{81}$ For the economic benefits of this increased production to be realized, the national pipeline network must be able to accommodate the transportation of oil and gas to new markets. As such, pipeline infrastructure is an essential component of the American oil and gas industry. ${ }^{82}$ There is no practical way, except through the use of pipelines, to transport natural gas from the well to the end user. While some alternatives do exist for the transportation of oil, such as railcars, pipelines provide the safest and most costeffective transportation method. ${ }^{83}$

80. PennEast Pipeline Co. v. New Jersey, No. 19-1039, 2020 WL 3492643 (U.S. June 29, 2020).

81. See The U.S. leads global petroleum and natural gas production with record growth in 2018, EIA.GOV (Aug. 20, 2019), https://www.eia.gov/todayinenergy/detail.php?id=40973\#: :text=The\%20United\% 20States\%20surpassed\%20Russia,world's\%20largest\%20producer\%20of\%20petro leum [perma.cc/6FRN-W7PB]; Ian Tiseo, World's leading gas exporting countries in 2019, STATISTA.COM (Sept. 2020) https://www.statista.com/statistics/217856/leading-gas-exporters-worldwide [perma.cc/B7B3-97R9]; EIA expects U.S. net natural gas exports to almost double by 2021, EIA.GOV (Jan. 23, 2020) https://www.eia.gov/todayinenergy/detail.php?id=42575 [perma.cc/Y8PU-DZ6K].

82. See Written Testimony of TSA Office of Security Policy and Industry Engagement Surface Division Director Sonya Proctor for a House Committee on Homeland Security, Subcommittee on Transportation Security Hearing Titled "Pipelines: Securing the Veins of the American Economy," TSA (Apr. 19, 2016), https://www.dhs.gov/news/2016/04/19/written-testimony-tsa-house-homelandsecurity-subcommittee-transportation-security [https://perma.cc/JYK2-QLYJ].

83. See General Pipeline FAQs, PiPELINE \& HAZARdous MATERIALs SAFETy ADMIN., https://www.phmsa.dot.gov/faqs/general-pipeline-faqs [perma.cc/4J899EY3] (last visited Nov. 3, 2020); Kenneth P. Green \& Taylor Jackson, Safety in the Transportation of Oil and Gas: Pipelines or Rail?, FRASER RESEARCH 1 (Aug. 2015), https://www.fraserinstitute.org/sites/default/files/safety-in-thetransportation-of-oil-and-gas-pipelines-or-rail-rev2.pdf [perma.cc/PME9-68L8]. 
As oil and gas production in the United States has surged, calls by environmental organizations and advocates to reduce or eliminate the use of fossil fuels have continued to grow louder. Recognizing the essential role of pipeline infrastructure in the oil and gas production system, opponents of fossil fuel production have pursued legal challenges against pipelines as a strategy to move towards their goal of fossil fuel reduction or elimination. The court rulings issued over the past year illustrate the impact that these legal challenges can have on the pipeline industry - delaying construction, increasing costs, and encouraging the abandonment of projects. ${ }^{84}$ There is no question that, viewed collectively, these rulings represent a serious blow to the further development of pipeline transportation projects and could dampen investors' confidence in unlocking and increasing the supply of oil and gas across the country. ${ }^{85}$

Because pipelines are indispensable to the fossil fuel industry, the expansion and construction of new pipelines will likely continue. ${ }^{86}$

84. See Marianne Lavelle, Climate Activists See 'New Era' After Three Major Oil and Gas Pipeline Defeats, InsideClimATENEWS.COM (July 7, 2020), https://insideclimatenews.org/news/07072020/pipeline-climate-victories-dakotaaccess-keystone-xl-atlantic-coast [perma.cc/Y6E9-DWFV]; Valerie Volcovici \& Stephanie Kelly, End of an Era? Series of U.S. setbacks bodes ill for big oil, gas pipeline projects, REUTERS (July 8, 2020, 6:07 AM), https:/www.reuters.com/article/us-usa-pipelines/end-of-an-era-series-of-u-ssetbacks-bodes-ill-for-big-oil-gas-pipeline-projects-idUSKBN2491M5 [perma.cc/D7QK-ATP9]; Keystone XL Pipeline, CENTER FOR BIOLOGICAL DIVERSITY,

https://www.biologicaldiversity.org/programs/public_lands/energy/keystone_xl_pi peline/\#: :text $=$ The $\% 20$ Keystone $\% 20$ XL $\% 20$ pipeline $\% 20$ could $\% 20$ be $\% 20$ an $\% 20$ environmental $\% 20$ disaster.\&text $=$ We're $\% 20$ fighting $\% 20$ to $\% 20$ make,energy $\% 20$ s ources\%20in\%20the\%20world [perma.cc/T27Z-FA5M].

85. See Hiroko Tabuchi \& Brad Plumber, Is This the End of New Pipelines?, N.Y.TIMES (July 8, 2020), https://www.nytimes.com/2020/07/08/climate/dakotaaccess-keystone-atlantic-pipelines.html [perma.cc/6JNZ-HAWF].

86. MVP Prepares for Construction Completion: Full In-Service Targeted Early 2021, Mountain VAlley PIPELINE 1 (June 11, 2020), https://www.mountainvalleypipeline.info/wp-content/uploads/2020/06/ScheduleCost-AppTrail-June-2020-FINAL3.pdf [perma.cc/GW4Y-EGXZ]; TC Energy reports strong first quarter financial results, TC ENERGY (May 1, 2020), https:/www.tcenergy.com/announcements/2020-05-01 tc-energy-reports-strongfirst-quarter-financial-results/ [perma.cc/CX2S-G8EK] ("... the Company announced that it was moving forward with construction of the Keystone XL pipeline project which will require an additional investment of approximately US $\$ 8.0$ billion. The pipeline is expected to enter service in 2023 and will play a critical role in connecting the world's third largest oil reserves in the Canadian oil sands with the continent's largest refining market in the U.S. Gulf Coast."); API Responds To Supreme Court Decision On Nationwide Permit 12, Keystone XL, API (July 6, 2020), https://www.api.org/news-policy-and- 
Based upon the string of recent legal victories by opponents of pipeline projects, however, it appears that the processes associated with the expansion and construction of these new pipelines have become more expensive, more time-consuming, and more uncertain in every respect.

issues/news/2020/07/07/nationwide-permit-program

[perma.cc/NAB7-Q8TY]

("The highest court has reinstated Nationwide Permit 12, and for good reason Pipelines are the backbone of America's energy infrastructure and the safest way to deliver affordable, reliable and cleaner energy to communities across the country. This is a significant step toward restoring more certainty for energy companies, but declining to revive the permit for Keystone XL is short-sighted as the project has already been thoroughly reviewed for well over a decade."). 